\title{
The Case for Integrating ePortfolio Pedagogy \\ into Nonprofit and Philanthropic Studies
}

\author{
Tyrone McKinley Freeman
}

\section{Introduction}

Over the past several decades, Nonprofit and Philanthropic Studies (NPS), an emerging interdisciplinary field, has adopted and developed an array of pedagogies in pursuit of a central question, “Can philanthropy be taught?” (Kass, 2002; McDougle, et. al., 2017). Some pedagogies, like service-learning, were adapted from elsewhere within the academy, while others, like student philanthropy (learning by giving), were developed by the field itself (Hatcher \& Studer, 2015; Campbell, 2014; Olberding, 2012). Electronic portfolio (ePortfolio) pedagogy, as a prominent teaching method used at more than half of all U.S. colleges and universities, is particularly well-suited for NPS (Rhodes, 2018), but has not received significant attention across the field. ePortfolios are student-created, web-based presentations of student learning and development designed for a particular audience (Yancey, 2019). Engaging students in the process of creating ePortfolios produces numerous educational benefits that speak directly to NPS's aspirations for its students as they graduate into their careers and lives as active citizens, and for itself as an emerging field continuing to establish its authority within the academy.

This article presents the potential of ePortfolios as a signature pedagogy for NPS and is based upon the literature and several years of experience teaching ePortfolios in an undergraduate capstone course within an NPS bachelor's degree program on a campus with a more than twenty-year record of ePortfolio implementation. After explaining what ePortfolios and ePortfolio pedagogy are, I argue that the strengths of ePortfolios are well-balanced to address key goals and particular considerations unique to NPS as an emerging and

This is the author's manuscript of the article published in final edited form as:

Freeman, T. M. (2020). The Case for Integrating ePortfolio Pedagogy Into Nonprofit and Philanthropic Studies. Journal of Nonprofit Education and Leadership, 10(3), Article 3. https://doi.org/10.18666/JNEL-2020-V10-I3-10245 
interdisciplinary field of inquiry in the $21^{\text {st }}$ century. Following this, I discuss challenges and caveats to consider when implementing ePortfolio pedagogy. Finally, I offer professional development resources to help NPS instructors and program administrators initiate or advance their use to further encourage engagement and broad adoption of ePortfolios across the field. ${ }^{1}$

\section{What are ePortfolios?}

ePortfolios are "web-based student-generated collections of learning artifacts (papers, multimedia projects, speeches, images, etc.) and related reflections, focused on learning and growth" (Eynon \& Gambino, 2017, 1). They typically take the form of a website (click for examples) within which learning artifacts are displayed and their meaning to the studentcreator's learning are integrated into a compelling story of personal and professional development. As such, ePortfolios provide "a framework for learning, a space for students to collect evidence of, reflect on, articulate, and create new learning over time" (Powell, Freeman \& Kahn, 2019, 1). Generally, according to Reynolds and Davis (2014), there are two types of ePortfolios, process and presentation. Process ePortfolios demonstrate the "journey" of student learning, that is, students' experiences of learning (4). Presentation ePortfolios, also known as product or project ePortfolios, enable students to share the results of their learning through a showcase of their best work and achievements from a course, program, internship or other learning context and for various audiences.

While traditional paper-based portfolios could enable students to present similar content, the digital nature of ePortfolios provides students access to hyperlinking, navigational options, and multimedia representations of their work (such as images, videos, social media, online

\footnotetext{
${ }^{1}$ My primary concern here is ePortfolio pedagogy as a High-Impact Practice in undergraduate NPS education, but ePortfolios can also be used at the graduate level and should be considered by the field as well.
} 
content, etc.) that add new dimensions and possibilities for expression, demonstration, and dissemination of their achievement (2014). ePortfolios are more readily sharable with larger audiences and easier to update through the internet than paper-based portfolios. The process of creating ePortfolios, which has been called "ePortfolio makingness," supports students in developing and mastering outcomes and competencies related to decision making, critical thinking, creativity, communications and collaboration (Yancey, 2019, 5), which are readily tied to both academic learning outcomes and the knowledge and skills employers say they desire in new hires. As such, “ePortfolios support powerful teaching and learning, assessment, student development, advising and career counseling, and professional and personal identity development along the pathway to graduation" (Powell, Freeman \& Kahn, 2019, 1).

ePortfolios have had significant presence and use in American higher education during the past 20 years. Approximately 57\% of American colleges and universities use ePortfolios with their students, and more than half of all college students report having used an ePortfolio during their college experiences (Eynon \& Gambino, 2017). ePortfolios are versatile as evidenced by their presence in a full range of public and private institutions. They can be found across various disciplines including world languages, English, and STEM-related fields. They are being used at all levels from first-year seminars to senior capstones and even in graduate and professional degree programs.

In 2017, ePortfolios were named one of eleven High-Impact Practices (HIPs), which are student-identified pedagogies and learning experiences that significantly enhance student success and retention at the undergraduate level and include first-year seminars, common intellectual experiences, learning communities, writing-intensive courses, collaborative assignments and projects, undergraduate research, diversity and global learning, service- and community-based 
learning, capstones, and internships (Kuh, 2008). HIPs have been empirically shown to have significant benefits upon student learning and development. When compared to their peers, students who engaged at least one HIP during their undergraduate experience spent more time preparing for class, interacted more regularly with faculty and peers, received more feedback on their performance, and applied and reflected upon what they learned more often (Watson, Kuh, Rhodes, Light, Chen, 2016). These effects were compounded the more students engaged in HIPs during their undergraduate career, and have shown to be particularly evident among first generation and underrepresented minority students. Ultimately, HIPs increase rates of student persistence and graduation (Kuh, 2008). ePortfolios were officially named a HIP because research has correlated effective ePortfolio pedagogy to increases in GPAs, pass and retention rates, accumulation of credit hours, and four-year graduation rates for students across the full spectrum of institutional types (Eynon, Gambino \& Torok, 2014; Watson, Kuh, Rhodes, Light \& Chen, 2016).

NPS has long been committed to extensive use of several HIPs because they pair well with the nature of the field and support student learning. For instance, service learning and internships are significant pedagogical tools in NPS. They are well represented among and, indeed, foundational to the four primary curricular models for delivering undergraduate education in the field (Dolch, Ernst, McCluskey, Mirabella \& Sadow, 2007). Capstones and internships are deeply ingrained in NPS graduate education as are other forms of experiential learning including practica and fieldwork (Carpenter, 2014). Additionally, student philanthropy or "learning by giving" coursework, which place students in the role of grant makers to give actual dollars to local community organizations, has emerged over the past two decades as a 
significant form of service-learning in NPS (Millisor \& Olberding, 2009; Olberding, 2012;

McDougle, et. al., 2017; McDonald, Miller \& McDougle, 2017).

But on the whole NPS has not been attentive to ePortfolio pedagogy. A literature search in leading education journals of the field yielded few results for articles focused on teaching ePortfolios within NPS. For instance, a few articles very briefly referenced ePortfolios in relation to assessment of student learning and development of faculty culture in NPS (Schmidt, 2014; Cantrell-Bruce \& Blankenberger, 2015; Blankenberger \& Cantrell-Bruce, 2016; Hatcher, Shaker \& Freeman, 2016), but ePortfolios were not central to the subjects under consideration. Another study noted that ePortfolios were a feature of an undergraduate fundraising internship program, but did not delve into their impact on student learning (Strickland \& Walsh, 2013). Further, if participation in the annual meetings of the Association for Authentic Experiential EvidenceBased Learning (AAEEBL), a leading academic association for ePortfolio teaching practice, is any indication, NPS is not well represented in this field. However, in addition to the aforementioned improved student success measures that HIPs offer, there are ample reasons why the NPS field should take up ePortfolios, in particular, as a signature pedagogy. Before presenting them, it is necessary to explain how ePortfolios function pedagogically.

\section{What is ePortfolio Pedagogy?}

At a rudimentary level, ePortfolio pedagogy involves guiding students through a deliberative process of collecting, selecting, reflecting, and presenting artifacts of their learning and achievement in a coherent and public manner of their own creation for a specific audience via an online platform (Reynolds \& Davis, 2014). Such artifacts may be drawn from a full range of student learning experiences and include, but are not limited to, research papers, presentations, 
speeches, group projects, lab reports, poems, and most other course assignments and activities meaningful to them. Artifacts may also include representations of learning from outside of the classroom such as occurs through internships, service learning, formal employment, leadership in student organizations, service on campus, and study abroad, etc. In NPS, specific academic artifacts could potentially include grant proposals, fundraising plans, philanthropic autobiographies, service learning reflections, social issue surveys, or comparative analyses of nonprofit sectors, while co-curricular artifacts could include documentation of volunteer board service, leadership or participation in advocacy campaigns, or fundraising for community needs. Such artifacts, with proper reflection and presentation, can document students' academic achievement to faculty and demonstrate their employability for nonprofit hiring managers.

However, the optimal HIP ePortfolio is more than "a scrapbook" or container for these items $(2014,4)$. On the range of effectiveness as a HIP, such an approach is less effective in manifesting deep student learning than what is being argued for here. Any type of ePortfolio can hold evidence of learning (e.g., the artifacts). However, a more effective high-impact pedagogy harnesses the decision-making and reflection processes involved in creating ePortfolios to exert influence on the demonstrated learning (Yancey, 2019). Students construct new learning from their collection of artifacts and integrate that new understanding with their identities as emerging professionals in their fields. This learning anew is made visible through ePortfolios that show the meanings within and connections between what students have already learned, what they can do as practitioners, and who they are as individuals. This important feature of ePortfolios is adaptable for the various approaches that undergird NPS programs whether they are focused on context, ethics, and leadership (Weber \& Witkowski, 2016; Baggetta and Brass, 2014; Burlingame, 2009); operational skills and technical employability (Blankenberger \& Cantrell- 
Bruce, 2016; O’Neill, 2005; Dolan, 2002); new critical analyses, social justice, and advocacy (Mirabella \& Nguyen, 2019; Mason, McDougle, et. al., 2019); or some combination thereof. But doing so requires effective pedagogy. ePortfolio pedagogy draws upon a variety of conceptual models of learning and student development including self-authorship, meaning-making, goal setting and attainment, life-long learning, hope theory, professional identity development, and constructivism (Buyarski et. al., 2015; Cordie, Sailors, Barlow \& Kush, 2019). But at its core, Eynon and Gambino (2017) have argued that ePortfolio pedagogy is reflective, integrative and social.

ePortfolio pedagogy is reflective because it engages students in meaning-making through the reexamination of their learning over time. Reflections, which are guided by prompts from faculty, may take a variety of forms including written, verbal, or multimedia with a focus on making meaning and connections between the spaces, places, and contexts in which learning has occurred (2017). The reflections "help make learning visible to students themselves" and the digital nature of the ePortfolio then translates that visibility for authentic audiences of peers, faculty, employers, and others external to the university (1). Here, pedagogy is essential because the process "requires thoughtful student action guided by well-informed faculty" (1). Facultyguided reflection is the centerpiece of ePortfolios and supports students in articulating connections between their learning artifacts and experiences, practicing relevant self-assessment which may have benefits throughout life, and in developing professional habits to inform their decision-making and career trajectories (Madden, 2015; Yancey, 2009; Doyle, 2011).

ePortfolio pedagogy is integrative because it enables students to make connections to learning that has occurred across courses, curricula, and contexts, including outside of the classroom, on campus and in the broader community (Eynon \& Gambino, 2017). These 
connections can also be made across time (e.g., semesters and academic terms) as well as disciplines, which is particularly important for NPS as an interdisciplinary field. The result of integrative learning is students' construction of "new identities as learners" (35). Through their ePortfolios, students represent their own learning in relation to the "delivered curriculum" (what faculty intended to be taught), the "experienced curriculum" (what was actually learned by students), and the "lived curriculum" (total learning to date) (Penny Light, Chen \& Ittelson, 2012, 8). This integrative characteristic is critical because students often limit their recognition of learning to specific coursework; ePortfolios enable them to engage multiple undergraduate experiences - in class, on the yard, in the dorms, in the community, on the job, overseas, etc.- as sources of learning.

The social nature of ePortfolio pedagogy is also foundational to ePortfolios' overall effectiveness in promoting deep student learning. In this case, social ePortfolio pedagogies are "design approaches for teaching and learning that engage students in authentic tasks that are communication-intensive, where the representation of knowledge for an authentic audience is absolutely central to the construction of knowledge" (Bass, 2014, 2). These practices facilitate the deepening of students' understanding, the communication of their understanding to make their own knowledge observable to others, and the students' focus on an authentic audience beyond the instructor, which adds value beyond a letter grade (2014). Relevant ePortfolio social pedagogies include faculty and peer feedback, collaborative assignments and projects, engagement of external audiences, and formation of communities of practice among students (2014), which refine employability skills for students, too. In such ways, students interact and collaborate with others as they reflect upon, construct, organize, and share their knowledge through the making of their ePortfolios. Eynon and Gambino emphasize that "Social pedagogy 
transforms ePortfolio learning from a solitary experience to one in which students engage with and construct knowledge through a community of learners" $(2017,30)$. In the process, their voice, agency, and identity as learners and emerging professionals are affirmed and elevated.

Overall, the inherent reflective, integrative and social nature of ePortfolio pedagogy aligns well with NPS's instructional goals for students and its own development as an emerging field in the academy.

\section{What Strengths does ePortfolio pedagogy offer Nonprofit and Philanthropic Studies?}

NPS's status as a new and emerging field creates part of the impetus for adoption and integration of ePortfolio pedagogy. Still relatively new to the academy and located within multiple spaces inside it, NPS has fought—and continues to fight— - hard to be taken seriously as a field of intellectual inquiry (Payton and Moody, 2008). The growth in degree programs and the establishment of a formal School of Philanthropy advance this effort. But, as Turner noted, the field "needs to articulate its place in advancing the pursuit of knowledge in general as well as to continue its contributions to the study of philanthropy" (2004, p. 2083). To accomplish this, the field must "spell out its distinctive focus and methods if it is to claim authority and importance for the products of its work. It needs to define the terms within which it can operate as an independent field or discipline" (2084). ePortfolio pedagogy contributes much to the articulation of such methods for a unique, growing and diverse field.

The nonprofit wing of NPS, based in schools of business, public administration, and continuing or professional education, is well-suited for ePortfolios given its focus on technical and managerial perspectives of operating nonprofit organizations (O’Neill, 2005). With curricula steeped in organizational theory, strategic planning, financial management, human resources, 
fundraising, such programs engage students in both theoretical foundations and applications which result in an array of perspectives, plans, policies, financial tools, and campaign structures as artifacts for engagement, reflection, and integration through ePortfolios. There may be a tinge more urgency for the philanthropic side of NPS, given its liberal arts orientation (Burlingame, 2009). Faced more squarely with the growing criticisms and shifting public attitudes about the value of a liberal arts education, philanthropic studies' focus on the "why" of philanthropy and the nonprofit sector requires continual consideration of how it best teaches students and helps graduates demonstrate and articulate their competencies and accomplishments in ways that resonate with employer expectations as well as the demands of citizenship. Consequently, ePortfolio pedagogy's emphasis on student identity development, integrative learning, and reflective practice lends itself as a valuable approach to teaching NPS, which has related concerns as a field preparing students for citizenship and the workforce.

\section{Identity Development}

NPS's own identity is still emerging. Its core subject, philanthropy, is hotly contested. Whether in definition, scope, or value, philanthropy can mean different things in different contexts, and can be simultaneously viewed as an essential element of functioning democratic societies and a controlling hegemonic force exalting private needs above the public good. These tensions make for a robust field that not only seeks to understand its subject, but also to inform its areas of practice (Donmoyer, 2009). Turner (2004) viewed this field as "a critical force operating on/in philanthropy as well as a contributor to relieving misery and improving the world" (2083). In this way, he observed that philanthropic studies has "an activist sense of itself...in having an impact on its world" (2084). In order to take a voluntary action to address a 
social need, however, one must ask oneself, "Who am I to intervene?” (Payton \& Moody, 2008). Voluntary action for the public good is moral action, and philanthropy is a mechanism for expressing one's values, advocating for positions, and seeking meaning in a larger society (2008).

As such, obtaining clarity surrounding one's own motivations, intentions, and understanding of social needs and others is critical. Accordingly, NPS seeks to develop students' understanding of their own identities, experiences, and values as they relate to their social commitments and taking voluntary action throughout their professional careers and lives as citizens (Weber \& Witkowski, 2016). ePortfolios are conducive to this goal because they emphasize "development of the 'whole' person by prompting students to connect and make meaning from diverse learning experiences which helps students develop more purposeful identities as learners... [and] to consider who they are and who they are becoming" (Kuh, Gambino, Ludvik \& O’Donnell, 2018, 19). These same questions have relevance for the NPS field seeking its own identity as a contributor to intellectual inquiry and a practical career pathway for graduates. ePortfolios can help make visible for the field its own knowledge about philanthropy as constructed by its students, its own identity as constituted within student representations of their learning, and its optimal teaching methods. The act of ePortfolio-making facilitates identity development in ways consistent with NPS's aspirations for its students that they recognize their connection to philanthropy, their efficacy as agents of it, and their abilities to take voluntary action and provide leadership in organizations.

\section{Integrative Learning}


ePortfolio pedagogy's strength in integrative learning highly recommends itself to NPS not only as an emerging field, but also as an interdisciplinary one. In a broad sense, integrative learning helps students in "connecting skills and knowledge from multiple sources and experiences; applying theory to practice in various settings; utilizing diverse and even contradictory points of view; and, understanding issues and positions contextually" (Huber, Hutchins \& Gale, 2005, 1). It enables students to bring together their learning from across disciplinary, classroom and even campus and community boundaries (Chen \& Penny Light, 2010; Richards-Schuster, et. al., 2014; Madden, 2015). ePortfolio pedagogy is grounded in such integrative practices because “an ePortfolio isn't a random compilation of loosely related artifacts but rather a focused genre telling a coherent story enriched by multiple artifacts all contributing to that narrative. Accordingly, the artifacts have to be linked, focused in some way for readers and reviewers to access and make sense of them" (Yancey, 2019, 5). Effective ePortfolio pedagogy is "inherently connective and integrative" centered on creating coherence and cohesion in increasingly fragmented post-secondary and lifelong learning environments (Eynon, Gambino \& Torok, 2014, 98; Eynon \& Gambino, 2017). A core benefit of ePortfolio pedagogy is that it establishes supportive scaffolding for student integration of learning and it develops their flexibility, adaptability and creativity as competencies for lifelong learning and the workplace in the $21^{\text {st }}$ century (Peet, et. al., 2011; Watson, Kuh, Penny Light, Chen, 2016).

\section{Reflective Practice}

Reflection is already a central feature of teaching in NPS, especially as it relates to the use of HIPs like service learning, internships, and student philanthropy (Hatcher \& Studer, 2015; Payton \& Moody, 2008). Indeed, the philanthropic autobiography, a reflective essay about 
students' early life experiences with philanthropy and the nonprofit sector, has been identified as a signature assignment and critical pedagogical tool in NPS (Payton \& Moody, 2008; Freeman, 2014; Hatcher, Shaker, Freeman, 2016; Hutchings, 2016). Because NPS “seeks to reflect on its subject as well as see its work carried forward into action in the world," developing reflective practitioners is a priority (Turner, 2004, 2084).

Reflection is "key to processing experience and the generation of meaning," which makes it a focal point of ePortfolio pedagogy, too (Eynon \& Gambino, 2017, 20; Watson, et. al., 2016). ePortfolio makingness requires students to reflect upon what they have learned so they can effectively and meaningfully curate their ePortfolios. But the kind of reflection needed is not simply reflection for its own sake; it is reflection grounded in metacognition. Reynolds \& Patton have described metacognition as "our ability to think about [our own] thinking. Specifically, it is understanding what we know, what we don't know, how we learn, and how we manage ourselves," which are central questions for NPS as an emerging field and for its graduates as reflective practitioners $(2014,96)$. ePortfolio pedagogy provides students with the structured time and space within a course, curriculum, or co-curricular learning experience "to consider and document the process of their learning and not just the product" (Penny Light, Chen, Ittelson, 2012, 11). This opportunity is vital because all too often students advance through their undergraduate courses, checking off boxes on their program plans without connecting their learning from course to course, semester to semester, year to year (not to mention co-curricular learning). Similarly, without an orientation toward reflective practice, philanthropy and nonprofit professionals can move from project to project, position to position, even organization to organization without stopping to think about the implications of their experiences for future actions and their overall professional identities. ePortfolio pedagogy is metacognition in action 
(Reynolds \& Patton, 2014). It enables students to develop and practice metacognitive skills in the creation of their ePortfolios, which emerge after graduation for use with employers and themselves as "physical evidence of [their] knowledge and self-reflection skills to form cohesive professional identities" (Ring, Waugaman \& Brackett, 2017, 232). By taking up ePortfolios, the NPS field would have a pedagogy tooled to develop students' thinking about their own thinking about philanthropy, which would help generate the desired reflective practitioners and, in turn, inform the field's understanding of itself.

Thus, ePortfolios are well suited as a signature NPS pedagogy for advancing the field's engagement with fundamental concerns surrounding its own emerging identity and its ability to nurture students' identities as agents of voluntary action; its interdisciplinary nature and the imperative of integrating students' learning across various contexts; and its value of reflection as the cornerstone of students' professional practice in the workforce. Still, there are challenges to consider when engaging the practice.

\section{Challenges in Teaching ePortfolios}

ePortfolios can have dramatic effects on student learning, but there are challenges NPS faculty may face when doing the pedagogy. These mostly relate to initiating ePortfolios as an add-on to existing course activities, preparing students for reflection upon artifacts, convincing students of the benefits, and determining what technology to use.

A key consideration is to ensure that ePortfolios are not simply an add-on to pre-existing course activities. Such an approach limits the impact of ePortfolios for students (Eynon \& Gambino, 2017). ePortfolios must be integrated into the course to facilitate the learning objectives and allocate adequate time to the process. Everything from instruction, activities and 
assignments must align with the ePortfolio and vice versa. Course assignments and supporting reflections may be submitted via the ePortfolio, which could be integrated into a learning management system. For instance, during a for-credit internship course, students could gradually construct an ePortfolio that captures the meaning of the work experience to them, the tangible deliverables they created on the job, and their articulations of the workplace knowledge and skills they developed in the process. But this takes time, and faculty will need to sequence and scaffold the ePortfolio throughout the course and collaborate with students in their ePortfolio makingness, rather than just add it to the list of assignments.

There are numerous models of reflection that can be used in NPS (Ash \& Clayton, 2009; Welch, 1999; Schon, 1983), but they must be scaffolded and prompted throughout the ePortfolio process. The key is to embed the model chosen with metacognition, as previously discussed. Students should not simply reflect upon the artifact itself, be it a paper, an internship project or service learning experience. They must contemplate the thinking processes used while doing the work represented by the artifact to bring to the surface how they approached the assignment, what problems arose during the process, how they managed those problems, and how their learning developed accordingly. Students tend to find this kind of reflection challenging, so they must be prompted and guided. Consequently, reflection should be iterative in ePortfolio pedagogy, providing students with significant practice and feedback towards improvement (Yancey, 2019).

Instructors may also find another challenge in convincing some students of the value of ePortfolios. Emphasizing the benefits for employment or graduate admissions may be helpful. According to a 2015 survey conducted on behalf of the AAC\&U, only $45 \%$ of employers found value in college transcripts for evaluating job applicants, while $80 \%$ said that ePortfolios 
demonstrating candidates' knowledge, skills, and accomplishments would be helpful in hiring decisions (Hart \& Associates, 2015). Relatedly, engaging in the process of creating ePortfolios has been shown to improve students' job interviewing skills and ability to positively selfpromote during the job search process (Ring, Waugaman \& Brackett, 2017; Cordie, et. al., 2019). That said, students will need to be proactive in their use of ePortfolios to support their job search strategies, and faculty will need to coach them. For instance, job-seeking students can include their ePortfolio URLs in their email signatures, and post them in their social media profiles. Students can also reference ePortfolios during job interviews as a way to build interest, and leave behind their URLs or send them along as part of follow-up thank you correspondence to interviewers. Pursuing these strategies requires ongoing attention to maintenance of the ePortfolio as well as tailoring them for particular audiences so that employers can easily navigate them.

Lastly, ePortfolios require the use of technology. There are numerous software platforms to choose from at various price points for any budget, including some freely available. While determining which platform to use is important, it is not the focus because "The starting question for ePortfolios is not which ePortfolio technology to adopt; it must be, 'What learning do we need?" where "we" includes students along with faculty, discipline, accreditors, and institution (Rhodes, 2018, 88). NPS instructors can take many steps toward engaging ePortfolio pedagogy before the issue of technology must be addressed. And there are numerous professional development resources available to help with such a selection.

\section{ePortfolio Resources and Professional Development}


Successful engagement of students in ePortfolio makingness depends upon specific instructional approaches and strategies including provision of clear guidelines and expectations, scaffolding, prompted reflection, and mentoring and coaching (Gordon, 2017). As a result, continuous professional development is essential for instructors teaching ePortfolios. There are numerous resources available to support NPS faculty seeking to engage in ePortfolio pedagogy, including professional associations and publications.

The Association for Authentic, Experiential, and Evidence-Based Learning (AAEEBL) is the leading professional development organization comprised of practitioners and researchers of ePortfolio pedagogy. A community of practice with approximately 1,400 individuals representing 12 countries and 5 continents, it is a global resource that regularly convenes meetings to share best practices in the field. It also publishes the AAEEBL ePortfolio Review, a peer-edited, theme-based magazine on pedagogy, research, technology, and program administration.

The Association of American Colleges \& Universities (AAC\&U) is a national association that promotes liberal undergraduate education. It maintains a membership of over 1,400 higher education institutions, is a key disseminator of research on HIPs in undergraduate teaching, and offers important resources for ePortfolios. It maintains the open access, double-blind, and peerreviewed International Journal of ePortfolio, which publishes theoretical, teaching, and evaluative articles. It also hosts Publications on ePortfolio: Archives of the Research Landscape (PEARL), an online peer-reviewed database of journal articles about ePortfolios. Additionally, as part of its annual national conference, AAC\&U partners with AAEEBL to host a 1-day Forum on Digital Learning and ePortfolios that includes sessions on using ePortfolios to support integrative student learning, assessment of student learning, and faculty professional development. 
The freely available ePortfolio High-Impact Practice Taxonomy is another valuable tool that can help NPS instructors (Powell, Freeman \& Kahn, 2019). Developed as a collaboration among faculty at Indiana University-Purdue University at Indianapolis, a Midwestern 4-year public urban research university, this taxonomy presents "the features of ePortfolios as a highimpact practice in individual courses, across degree and co-curricular programs, and across entire undergraduate experiences" $(2019,1)$. Faculty at the institution have been using ePortfolios extensively throughout undergraduate education for the past two decades. The taxonomy is the result of their experience and extant research. This taxonomy describes in detail the primary attributes of well-done ePortfolio pedagogical practices to guide instructors, whether novice or veteran, in their planning and implementation of ePortfolio pedagogy.

\section{Conclusion}

ePortfolios have the potential to be a signature pedagogy in NPS because, by their very nature, they facilitate many of the field's aspirational goals for its students in the classroom and for itself in the academy. The integrative, reflective and social nature of ePortfolios as a pedagogy blend well with NPS's interdisciplinary composition and emphasis on producing reflective practitioners who can work well with others, and understand and take voluntary action to address a range of social issues. Just as the field has taken to service-learning and other forms of HIPs, ePortfolios are an important and widely available option—and recently named HighImpact Practice - to consider. By engaging students' own identity development and capacity for integrative learning, this pedagogy can help NPS continue its own efforts toward self-definition with the aid of students' ePortfolio articulations of the learning that has been most meaningful to them. . 


\section{Bibliography}

Ash, S.L. \& Clayton, P.H. (2009). “Generating, Deepening, and Documenting Learning: The Power of Critical Reflection in Applied Learning," Journal of Applied Learning in Higher Education, v.1, (Fall), 25-48.

Baggetta, M. \& Brass, J.N. (2014). “Context-based Instruction: What Traditional Social Science Disciplines Offer to Nonprofit Management Education," Journal of Public Affairs Education, 20(4), 579-596.

Bass, R. (2014). "Social Pedagogies in ePortfolio Practices: Principles for Design and Impact." Catalyst for Learning: ePortfolio Resources and Research, September 1, 2019, http://c21.mcnrc.org/wp-content/uploads/sites/8/2014/01/Bass_Social_Pedagogy.pdf.

Blankenberger, B. \& Cantrell-Bruce, T. (2016). "Nonprofit Education: Evaluating and Assessing the Skill Sets Our Students Learn," Journal of Nonprofit Education and Leadership, 6(3): 243-253.

Burlingame, D.E. (2009). "Nonprofit and Philanthropic Studies Education: The Need to Emphasize Leadership and Liberal Arts," Journal of Public Affairs Education, 15, 1 (Winter), 59-67.

Buyarski, C., Aaron, R., Hansen, M., Hollingsworth, C., Johnson, C. Kahn, S., Landis, C., Pedersen, J. \& Powell, A. (2015). "Purpose and Pedagogy: A Conceptual Model for an ePortfolio," Theory into Practice, 54(4), 283-291.

Campbell, D. (2014). "Practicing Philanthropy in American Higher Education: Cultivating Engaged Citizens and Nonprofit Sector Professionals," Journal of Public Affairs Education, 20(2), 217-231.

Cantrell-Bruce, T. \& Blankenberger, B. (2015). "Seeing Clearly: Measuring Skill Sets that Address the 'Blurred Boundaries' of Nonprofit Management Education," Journal of Public Affairs Education, 21(3), 367-380.

Carpenter, H.L. (2014). "A Look at Experiential Education in Nonprofit-Focused Graduate Degree Programs," Journal of Nonprofit Education and Leadership, 4(2), 114-138.

Chen, H.L. \& Black, T.C. (2010). 'Using E-Portfolios to Support an Undergraduate Learning Career: An Experiment with Academic Advising." Educause Quarterly, 33(4). Retrieved September 30, 2019 from https://www.learntechlib.org/p/109184/.

Chen, H.L. \& Penny Light, T. (2010). Electronic Portfolios and Student Success: Effectiveness, Efficiency, and Learning. Washington D.C.: Association of American Colleges \& Universities. 
Cordie, L., Sailors, J., Barlow, B. \& Kush, J. (2019). “Constructing a Professional Identity: Connecting College and Career through ePortfolios," International Journal of ePortfolio, $9(1), 17-27$.

Dolan, D. (2002). "Training Needs of Administrators in the Nonprofit Sector: What are They and How Should We Address Them?” Nonprofit Management \& Leadership, 12, 3 (Spring), 277-292.

Dolch, N., Ernst, M., McClusky, J.E., Mirabella, R.M. \& Sadow, J. (2007). "The Nature of Undergraduate Nonprofit Education: Models of Curriculum Delivery," Journal of Nonprofit Education and Leadership, 36(4), 28S-50S.

Donmoyer, R. (2009). Theories about the Role of Theory in Nonprofit and Philanthropic Studies," Nonprofit \& Voluntary Sector Quarterly, 38, 4: 701-713.

Doyle, T. (2011). Learner-Centered Teaching: Putting the Research on Learning into Practice. Sterling, VA: Stylus Publishing.

Eynon, B. \& Gambino, L. (Eds.). (2018). Catalyst in Action: Case Studies of High-Impact ePortfolio Practice. Sterling, VA: Stylus Publishing.

Eynon, B. \& Gambino, L. (Eds.) (2017). High-Impact ePortfolio Practice: A Catalyst for Student, Faculty, and Institutional Learning. Sterling, VA: Stylus Publishing.

Eynon, B., Gambino, L. \& Torok, J. (2014). "What Difference Can ePortfolio Make? A Field Report from the Connect to Learning Project," International Journal of ePortfolio, 4(1), 95-114.

Freeman, T. M. (2014). Your philanthropic autobiography. Indiana University-Purdue University Indianapolis. Retrieved from https://www.learningoutcomesassessment.org/assignment-library/your-philanthropicautobiography/

Gordon, L. (2017). "Students as Co-Designers: Peers and Instructional Resources for Novice Users of ePortfolios," International Journal of ePortfolio, 7(2), 113-127.

Hart \& Associates. (2015). Falling Short? College Learning and Career Success. Association of American Colleges \& Universities. Retrieved August 10, 2019 from https://www.aacu.org/leap/public-opinion-research/2015-survey-results.

Hatcher, J. \& Studer, M. (2015). "Service-Learning and Philanthropy: Implications for Course Design," Theory into Practice, 54(1), 11-19.

Hatcher, J., Shaker, G., \& Freeman, T (2016). "Faculty Learning Communities: Taking Collective Action to Improve Teaching and Learning in Nonprofit and Philanthropic Studies," Journal of Nonprofit Education and Leadership, 6(3), p. 254-272. 
Huber, M., Hutchings, P. \& Gale, R. (2005). Integrative Learning for Liberal Education.” Peer Review, 7(3/4). Downloaded from August 10, 2019 from https://www.aacu.org/publications-research/periodicals/integrative-learning-liberaleducation.

Hutchings, P. (2016). "Aligning Educational Practices and Outcomes.” (Occasional Paper No. 26). Champaign, IL: National Institute for Learning Outcomes Assessment. Retrieved August 10, 2019 from https://www.learningoutcomesassessment.org/wpcontent/uploads/2019/02/OccasionalPaper26.pdf

Kass, Amy. (2002). The Perfect Gift: The Philanthropic Imagination in Poetry and Prose. Bloomington: Indiana University Press.

Kuh, G. (2008). High-Impact Educational Practices: What They Are, Who has Access to Them, and Why They Matter. Washington D.C.: Association of American Colleges \& Universities. Downloaded July 8, 2019 from https:/www.aacu.org/leap/hips

Kuh, G., Gambino, L. M., Ludvik, M.B., \& O’Donnell, K. (2018, February). Using ePortfolio to document and deepen the impact of HIPs on learning dispositions (Occasional Paper No. 32). Urbana, IL: University of Illinois and Indiana University, National Institute for Learning Outcomes Assessment (NILOA). https://www.learningoutcomesassessment.org/wpcontent/uploads/2019/02/OccasionalPaper32.pdf

Madden, T.M. (2015). "Reimagining Boundaries: How ePortfolios Enhance Learning for Adult Students," International Journal of ePortfolio, 5(1), 93-101.

Mason, D.P., McDougle, L. \& Jones, J.A. (2019). “Teaching Social Justice in Nonprofit Management Education: A Critical Pedagogy and Practical Strategies," Administrative Theory \& Praxis, DOI: 10.1080/10841806.2019.1643615

McDonald, D., Miller, W.M., McDougle, L. (2017). “Connecting through Giving: Understanding the Effect of the Mayerson Student Philanthropy Project," Journal of Nonprofit Education and Leadership, 7(2), 110-122.

McDougle, L., McDonald, D., Li, H., Miller, W. \& Xu, C. (2016). “Can Philanthropy be Taught?” Nonprofit \& Voluntary Sector Quarterly, 46(2), 330-351.

Millisor, J. \& Olberding, J.C. (2009). "Student Philanthropy in Colleges and Universities." Academic Exchange Quarterly, 13(4), 11-16.

Mirabella, R. \& Nguyen, K. (2019). "Educating Nonprofit Students as Agents of Social Transformation: Critical Public Administration as a Way Forward," Administrative Theory \& Praxis, DOI: 10.1080/10841806.2019.1643616

Olberding, J.C. (2012). "Does Student Philanthropy Work? A Study of Long Term Effects of the 'Learning by Giving' Approach," Innovations in Higher Education, 37(2), p. 71-87. 
O’Neill, M. (2007). “The Future of Nonprofit Management Education.” Nonprofit \& Voluntary Sector Quarterly, 36, 4, 169S-176S.

O’Neill, M. (2005). "Developmental Contexts of Nonprofit Management Education," Nonprofit Management \& Leadership, 16, 1, 5-17.

Payton, R. \& Moody, M. (2008). Understanding Philanthropy: It's Meaning and Mission. Bloomington: Indiana University Press.

Peet., M., Lonn, S., Gurin, P., Boyer, K., Matney, M., Marra, T. Taylor, S. \& Daley, A. (2011). "Fostering Integrative Knowledge through ePortfolios," International Journal of ePortfolio, 1(1), 11-31.

Penny Light, T., Chen, H.L. \& Ittelson, J.C. (2012). Documenting Learning with ePortfolios: A Guide for College Instructors. San Francisco, CA: Jossey Bass.

Powell, A.A., Freeman, T., Kahn, S. (2019). ePortfolio High-Impact Practice Taxonomy. Retrieved from http://rise.iupui.edu/taxonomies

Reynolds, N. \& Davis, E. (2014). Portfolio Keeping: A Guide for Students. New York: Bedford/St. Martin's.

Reynolds, C. \& Patton, J. (2014). Leveraging the ePortfolio for Integrative Learning: A Faculty Guide to Classroom Practices for Transforming Student Learning. Sterling, VA: Stylus Publishing.

Richards-Schuster, K., Ruffolo, M., Nicoll, K., Distelrath, C., Galura, J. (2014). "Using ePortfolios to Assess Program Goals, Integrative Learning, and Civic Engagement: A Case Example," International Journal of ePortfolio, 4(2), 133-141.

Ring, G., Waugaman \& Brackett, B. (2017). "The Value of Career ePortfolios on Job Applicant Performance: Using Data to Determine Effectiveness," International Journal of ePortfolio, 7(2), 225-236.

Rhodes, T. (2018). "Lift Every Voice: ePortfolios for Creating and Integrating." International Journal of ePortfolio, 8(2), 87-89.

Schmidt, S. T. (2014). "Pathways and Peril: The State of Undergraduate Nonprofit Studies," Journal of Nonprofit Education and Leadership, 4(1), 4-10.

Schon, D. (1983). The Reflective Practitioner: How Professionals Think in Action. New York: Basic Books.

Strickland, S. \& Walsh, K. (2013). "Fostering Future Fundraisers through a Model Undergraduate Internship Program," Journal of Nonprofit Education and Leadership, $3(1), 5-17$. 
Turner, R. (2004). "Philanthropic Studies as a Central and Centering Discipline in the Humanities," International Journal of the Humanities, 2(3): 2083-2086.

Watson, C.E., Kuh, G., Rhodes, T., Penny Light, T., Chen, H.L. (2016). “Editorial: ePortfolios: The Eleventh High-Impact Practice,” International Journal of ePortfolio, 6(2), 65-69.

Weber, P.D. \& Witkowski, G.R. (2016). "Philanthropic Disruptions: Changing Nonprofit Education for an Engaged Society," Journal of Public Affairs Education, 22, 1 (Winter 2016): 91-106

Welch, M. (1999). "The ABCs of Reflection: A Template for Students and Instructors to Implement Written Reflection in Service-Learning," NSEE Quarterly, 25, 22-25.

Yancey, K. (2009). "Reflection and Electronic Portfolios: Inventing the Self and Reinventing the University," in D. Cambridge, B. Cambridge \& Yancey, K. (eds.). Electronic Portfolios 2.0: Emergent Research on Implementation and Impact. Sterling, VA: Stylus Publishers, 5-16.

Yancey, K. (2019). ePortfolio as Curriculum: Models and Practices for Developing Students' ePortfolio Literacy. Sterling, VA: Stylus Publishers. 